\title{
CHANGE OF STUDENTS' ACTIVITIES IN THE PROCESS OF BECOMING A TEACHER
}

\begin{abstract}
The article presents a part of research focused on teacher education in Poland. Becoming a teacher is a process that takes place in the space of universities and schools as educational entities in which two discursive communities meet. The distinctness and the hermetic character of the communities are an epistemological barrier to the creation of cooperation, which is essential for effective teacher education. The research is directly related to the need to introduce changes in this area and to define the conditions for these changes to occur.

The purpose of the research is to establish how an institution which trains teachers functions. In order to achieve this goal, the author reconstructs a set of rules of discursive practices which were revealed during a group discussion among the students. In the research, a reconstructive formula based on critical discourse analysis was adopted. On the basis of the analysis, recommendations for the practice of teacher education are offered.
\end{abstract}

Keywords: becoming a teacher, discursive community, critical discourse analysis

\section{SPREMEMBA DEJAVNOSTI ŠTUDENTOV, KO POSTAJAJO UČITELJI - POVZETEK}

Članek predstavlja del raziskave, ki se osredotoča na izobraževanje učiteljev na Poljskem. Proces, v katerem nekdo postane učitelj, se odvija v prostoru univerz in šol kot izobraževalnih entitet, kjer se srečujeta dve diskurzivni skupnosti. Specifičnost in hermetična narava teh skupnosti pomenita epistemološko oviro za ustvarjanje sodelovanja, ki pa je za učinkovito izobraževanje učiteljev nujno. Raziskava se neposredno navezuje na potrebo po uvajanju sprememb na tem področju in po definiranju ustreznih pogojev, da bi do teh sprememb lahko prišlo. Namen raziskave je ugotoviti, kako deluje inštitucija, ki usposablja učitelje. Za namen doseganja tega cilja avtorica rekonstruira množico pravil diskurzivnih praks, kakor so se razkrila skozi skupinsko razpravo med študenti. V raziskavi je bila uporabljena formula za rekonstrukcijo, ki temelji na kritični analizi diskurza. Na podlagi analize so podana priporočila za prakso izobraževanja učiteljev.

Ključne besede: postati učitelj, diskurzivna skupnost, kritična analiza diskurza

Joanna Malinowska, PhD, Faculty of Historical and Pedagogical Sciences, University of Wroclaw, joanna.malinowska@uwr.edu.pl 


\section{INTRODUCTION}

Polish educational policy regarding preparation for the teaching profession is defined in a document entitled Teacher Education Standards (2012), which has been in force since the academic year 2012/2013. In Poland teacher education is administered by the Ministry of Science and Higher Education. The Ministry of National Education (responsible for the education of children and young people) does not have any influence on the process. Although educational reports emphasize the fact that effective teacher training is the starting point for meeting the challenges of the 21st century and for effective school education in Poland, the division into the Ministry of National Education and the Ministry of Science and Higher Education means that there is no current coordination. The specific demands in the area of teacher education are not analyzed from the perspective of the needs of modern schools. This is why modernization is necessary in the approach to vocational teacher training within the existing educational policy. Such changes are possible to accomplish despite the division of competences between the individual ministries.

From the point of view of becoming a teacher, it is very significant is that the students who are preparing for a new career role are on the threshold of early adulthood. This is a dynamic period during which they make choices that determine the future of their lives and their position in the generational structure; the greater the students' personal commitment and experience in identifying and solving problems, the greater the efficiency of learning. Meta-systemic and relativistic thinking are characteristic of this period. At the basis of such thinking lies the conscious and hierarchical structure of values, which influences how students create their own vision of the world. In situations where students experience values different from their own, contradictions that can block the change of thinking about the world manifest themselves. In this context, it is worth looking into the conditions in which candidates hoping to become teachers of young children build their professional identity and their own vision of functioning in the education system.

The issue of becoming a teacher, which is analyzed in the article, is located at the border of two worlds of education: teacher-practitioners and teacher-candidate students. During their internship, students face the necessity of using scientific thinking about education (academic approach) in interpreting real-school educational reality (Szempruch, 2013). These questions emerged during the implementation of the new professionalism-related teacher education concept. A special place in this concept is given to the teaching internship that is part of the learning process.

In this paper, we propose to combine the undergraduate internship - understood by Peter Jarvis (2012, p. 19) as reflective practice - with the bachelor thesis requirement. The proposal is based on the belief that becoming a teacher is a process which takes place in the space of universities and schools, which are educational entities ${ }^{1}$. The results of such an

1 The proposal refers to students of pedagogy with a specialization in early school and pre-school education at the Institute of Pedagogy, University of Wroclaw. This procedure promotes reflective action and, as a consequence, improves a broad spectrum of competences that future teachers acquire. An integral part of the 
approach to teacher education have been promising: the students have proven themselves able to overcome stereotypes and abandon the previously observed applicative and instrumental method of planning educational activities; a tendency to copy ready formulae has disappeared over time.

There has also been a change in the way students approach knowledge. Recognizing connections between academic knowledge and the possibility of using it in their own work, students evinced a high level of intrinsic motivation to seek sources of information outside their formal education and to complement and expand their knowledge (Malinowska, 2014). At the same time, students - while undergoing teaching practice - experienced contact with a different way of understanding the world of education, resulting from a different type of knowledge which is presented by the teacher. Since each form of knowledge is its interpretation through which an attempt is made to organize the educational reality, teachers and students organize this reality from different perspectives. Therefore, they form small distinct communities based on the fact that during the course of experiences and everyday life they formulate their own thinking styles, understandable within the particular group, and even mental coercion (Zemło, 2006, p. 171).

For that reason we may say that the two communities meet in the school space. Each of the communities is rooted in its shared meanings and practices ${ }^{2}$. In each community events are interpreted in specific contexts and, as a result, the intra-group specificity of constructing the worlds makes them hermetic and closed off from the other worlds, which is the result of interpreting events. As outsiders, with their knowledge different from knowledge which is shared by teachers (Mannheim, 2008), students experience discomfort while placed within the school reality. That is because it is the teacher who evaluates the students' comments on their actions on the basis of her own world. In this sense, a student in school is subjected to the teacher's knowledge or power. In contact with the students' perception of the education world, which is different from their own, teachers adopt the strategy of leveling and breaking otherness (Bauman, 2000). The aim of the strategy is to impose on the students specific frameworks of reality interpretation. Teachers seek validation of the presented posture in discursive negotiation of meanings and in assigning dominant meanings to certain values. Therefore, the world of education has a discursive character. Segregation of threads/motives which are present, absent or poorly outlined in the discourse is the basis for the construction of this world. Ewa

thesis is a program of educational activities which is developed by students during their seminars. During the undergraduate internship (continuous internship after the fifth semester), students have the opportunity to give lessons which are based on the prepared program. After they have finished teaching, they evaluate their own activities. Pedagogical reflection, self-evaluation and description of areas that require changes are all reflected in the final part of the thesis. This organization of students' work aims to create optimal conditions for the construction of the students' own educational theories. Furthermore, it combines two learning strategies: learning before taking action and learning while taking action.

2 The concept of practice is used in the sense of conscious and committed actions of individuals. These actions are shaped by values and meanings which are socially constructed in the discourses. See: Beck, Giddens and Lash, 2009. 
Rodziewicz (2011) describes the phenomenon as a peculiar supervision of meanings in the educational space.

Assuming that learning which involves conversion of previous knowledge into a different kind of knowledge is a discursive experience, we might say that during the process of becoming a teacher, a student's knowledge is generated under conditions of inequality of social relations and domination by school teachers and academics who impose their meanings. Therefore knowledge is constructed as a result of interpretative coercion (Zemło, 2006). In this perspective, the institutions of school and university are the centers of power students are subjected to and the space where the identity of future teachers is formed.

For an effective implementation of the proposed model of teacher education, cooperation between teachers, students, and teachers of teachers (academics) is required. The manifested difference of education worlds is a type of epistemological obstacle in building this cooperation, because authentic change cannot be initiated by an external stimulus and the subjects must be deeply involved in the creation of the new quality. This type of engagement can be achieved in the process of social arrangements that have a negotiating character in agreement-oriented interactions and are free of domination. Cooperation requires then, on the one hand, a reduction in the autonomy of groups and individuals, and the preservation of their identities, on the other. The subject of the research - the process of becoming a teacher - has a direct relationship with the need to introduce changes into teacher education and with the determination of the conditions for these changes to occur. The aim of the research is to discover how an institution that trains teachers functions by recognizing the way discourse participants act, think and feel (Kubinowski, 2010). This draws attention to the educational discourse in which the process of becoming a teacher takes place, and to the search for answers to the following questions:

- What discursive community do students build in the process of becoming teachers?

- In what educational discourses do students build their teacher identity?

- What way of thinking about the teacher does student discourse reveal?

The answers to these questions may be found in discursive practices, i.e., the ways of producing and receiving texts in communication activities. Therefore critical discourse analysis, which allows to reconstruct a set of rules of discursive practices present in the analyzed texts, was used in the research (Gee, 2014).

\section{RESEARCH PERSPECTIVE}

To adopt a clear and coherent research procedure, a conceptualization of discourse is necessary. This work is carried out under the assumption that the semantic scope of discourse as a concept includes a clash of ideas, interpretation of meanings and multiplication of alternatives which are supported by arguments. Therefore in discourse, views and opinions are revealed, meanings are communicated, events and their importance are determined. According to Foucault, discourse is a structured whole which reflects the complex interrelationship of knowledge/power. 
With regard to educational discourse, we might claim that power/knowledge is based on the well-established way of thinking about education and its subjects/participants, and is represented by the experts. It is they who impose patterns of concepts and ways of thinking. Understood in these terms, the identification of discourse requires the discovery and disclosure of the mechanisms of power abuse and domination.

According to Teun A. van Dijk, discourse is a communication event which comprises "(a) the use of the language, (b) the transmission of ideas and (c) interaction in social situations" (2006, p. 1021). In this approach, discourse can be understood as an interactive event which is equated with the determination of the meaning of education and/ or which takes place during education. The construction of teacher identity occurs during these interactions. Identifying this type of discourse requires taking into account the educational interests of the participants, types of knowledge about education which they represent, and their competence in the use of this knowledge (Hejnicka-Bezwińska, 2008, p. 467).

Combining both positions, I assume that discourse occurs in social interactions and it is the deliberate use of language by education participants in order to communicate in which unbalanced relationships among education entities are evident. It is thus an organized and relatively structured form of expression; it is revealed in the language and mode of action of persons by means of language. The content and form of linguistic behavior are determined by the cognitive concepts of discourse participants, as well as by the practical conditions of formulating utterances (Foucault 2002, p. 16).

Discourse refers to subjective interactive relationships among the participants that form a discursive community. Therefore discourse is the collective structuring and practice of knowledge. Communication which creates a sense of connection between the members is made simple within the discursive community. Because "a discourse community recruits its members by persuasion, training or relevant qualification" (Swales, 1990, p. 24), we might say that in the course of their studies, students become such a community, which is characterized by - according to Swales - defined communication objectives and determined mechanisms of internal communication. The implementation of these objectives by community members is done using a language (ibid.) that does not belong to the sphere of the individual but to the sphere of the community (Gadamer, 2000). A sense of community can always be observed from the outside through the analysis of community members' utterances.

Discourse may be examined - depending on the goals - using different analytical approaches (Bosančić and Keller, 2016). Critical discourse analysis (CDA) does not belong to a particular theory of discourse or research school (Jabłońska, 2013). The point of CDA is to promote social change. By approaching communication integrally (i.e., taking into account the linguistic, psychological and sociological aspects), CDA studies the transfer of ideas and the impact language usage may have on people in the context of power abuse, domination or inequalities that the discourse expresses or reproduces (van Dijk, 2001). 
The phenomenon of becoming a teacher, which is a fragment of educational reality, is immersed in context. Certain ways of thinking of discourse participants are formed in a given social context, but at the same time they influence the context (Carr and Kemis, 1995).

The social context, which refers to the communication situation, has a complex hierarchical structure that consists of two levels. The local level refers to the characteristics of the participants, situation, place and time of the meeting and the course of the event during which the world is built up again. As a result, the situation is changeable (Rancew-Sikora, 2007). At the same time, the situation is embedded in a global context level, which comprises institutions or social macrogroups.

Knowledge of the situational context and its analysis is essential for understanding utterances produced by discourse participants. It makes possible the discovery of the justification for actions undertaken "here and now". Access to discourse is only possible through texts. The unit of CDA analysis is the discourse - the whole text understood as a material product of language activities. Therefore also the language context is analyzed. This is pointed out by Van Dijk, who highlights the fact that the dimensions of discourse (speech acts, ideas, interactions) are also elements of the discourse context (Bielecka-Prus, 2012).

\section{RESEARCH DESCRIPTION}

Taking into account the theoretical references to discourse and using the CDA approach, I adopt the research procedure proposed by Ian Parker (2004). It consists of the following stages.

The text which is to be analyzed should be turned into a written form, if it is not already.

- In the next phase cultural networks accessed by free association to varieties of meaning should be noted down.

- The objects, usually marked by nouns, should by systematically itemized in the text or selected part of text.

- Distance from the text should be maintained. This can be achieved by treating the text as the object of research rather than what it seems to "refer" to.

- The "subjects" (i.e., characters, personas, role positions) specified in the text should be systematically itemized.

- The rights and responsibilities of "subjects" specified in the text should be reconstructed.

- The networks of relationships should be mapped into patterns. These patterns in language are "discourses" and may be located in relations of ideology, power, and institutions.

In order to gather empirical material, a focused group interview was conducted with a natural group which included 16 students of early school and pre-school education. The participants share experience regarding the education process (Lisek-Michalska, 2013). In the interview, the dynamics based on mutual interactions of the group were used. The discussion, which was part of seminar classes, took place a week after the students had finished their undergraduate internship. The moderator's participation was reduced to a secondary role and consisted of presenting the topic of discussion; however, she did not 
direct the discussion. The question regarding the students' vision of themselves as good teachers of children opened the discussion. The discussion ended naturally after $90 \mathrm{~min}-$ utes. When communicating with each other, students agree on the shape of the education world and talk about issues related to their educational practice. Because of the roles students play, they are part of the education world, and therefore they acquire general abilities to act (Habermas, 1986).

An empirical analysis was performed on the text of the recorded conversation of last semester undergraduate students. By taking into account connections between the actions of individuals and the structure which determines these actions, it is possible to reveal discursive practices. It is therefore important to define the institutional context that surrounds the emergence of discourse. The students who participated in the discussion began their studies and studied at the time curriculum changes were introduced. The changes included a new concept of teacher education.

In order to adapt the educational offer to the national qualifications framework, particular emphasis was placed on the development of prospective teachers' competences. This approach was reflected in the intended learning outcomes. The curriculum content and methods of working with students were constructed in relation to the requirements of the labor market and the social constructivist model of school education. At the same time, students joined the discussion on the possibility of implementing this model in schools, which had been ongoing in academic circles, through participation in open debates, scientific conferences and seminars.

The volume of the analyzed text is 42,138 characters without spaces. The transcription of the recording is not a perfect reflection of the discussion. Therefore the text analysis was complemented by an analysis of the recorded audio material. The participants in the discussion communicate using natural language, which is the main carrier of meaning. The language of the students is constitutive of their world, because "it provides implicature frameworks that create context, at the same time it establishes the possible connections which are ready for language users" (Niżnik, 1996, p. 29).

The colloquial style reflects the students' knowledge about "educational processes, including educational paradigms expressed in the form of pedagogical doctrines, educational ideologies or reconstructed hidden curriculums" (Hejnicka-Bezwińska, 2008, p. 263). The language-based process of putting order into the world of language education results in the creation of a semantic field that determines activities and learning situations. The choice of register is conditioned by the communication situation. During the discussion, the strategy of direct communication was assumed - message exchanges occur in a natural everyday situation (the students are an educational group) and between equal partners who are familiar with each other. The syntax, vocabulary and structure of the content are characteristic of spoken text which is created spontaneously. Colloquial expressions can be found in the text next to pedagogical terminology. This shows that the terminology was integrated into everyday language. The aim of the discussion was to 
determine the changes that had occurred in the manner students thought about teachers, to look at themselves in the role of the teacher from the perspective of the student experience and self-assessment of their own functioning in the classroom. The subject of the analysis and reflection is the change of the participants' practices in the process of becoming a teacher. An overview of this change is done from two perspectives: internal (of the students themselves) and external - from the perspective of the researcher ${ }^{3}$. Interpretation does not apply to individual practices but to collective beliefs and patterns of action.

The presentation of the analysis is part of ongoing research on the issue of becoming a teacher. With regard to the adopted theoretical perspective and research purposes, I focus on the following:

- analysis of the thematic-rhematic structure,

- analysis of the discursive strategies,

- analysis of selected speech acts.

Selected categories of analysis will allow us to define the conceptual frame as a way of interpreting events and their transformation in the discourse, as well as to determine the manner in which the students persuade others to share their point of view. This, in turn, will allow us to answer the research questions. In the present article it is not possible to present all the detailed analyses. Only elements that justify the conclusions and recommendations regarding the concept of undergraduate internship were selected for presentation.

\section{RESEARCH RESULTS}

The global theme of the discourse was chosen as a result of the analysis of specific topics included in the ensuing paragraphs of text. The division of the text into paragraphs was based on the idea of marking the moment when new speakers who pick up and develop a new thread are joining the discussion and of marking the moment when a new topic is introduced. As a result of the thematic analysis, which involved combining specific topics into thematic bundles, a map of discourse content was created. The global topic was the preliminary information known to students (the role of the teacher in the context of implementing the social-constructivist model of education), which provided a frame of reference for bringing into the discussion new elements which helped to expand the topic.

From among the individual utterances/paragraphs, several topics were selected. The analysis of these topics reveals four evaluative theses posed by the students:

- for years, teachers have been recreating existing patterns of action,

- there are no good role models,

- students cannot pursue their vision of a good teacher, they must fit into the existing scheme,

- young teachers who start work have no freedom of action,

3 I was present during the student discussion, but I did not participate in it in order not to interfere with its course. As a researcher, I could not only analyze the text but also observe participants, their reactions and non-verbal behavior. 
leading to the following conclusion: in order to make changes, you need to cheat/swindle and be crafty.

A rhematic analysis allowed us to determine what the most important informative part of the utterance is, what the message is regarding being a school teacher and the ability to pursue the students' own vision of a good teacher. The necessity of cheating, writing lesson plans as a meaningless activity, fraud as the only strategy that allows changes these are the topics that emerged at the beginning of the conversation. These topics were emphasized by the fact that the following speakers referred to them and elaborated on them. This thematic persistence indicates that they are of great importance to the participants of the discussion. Rhematization becomes evident in the syntax structure of the text: contrast is used in a large number of sentences (I will not do any of the things the teachers did; there was no teacher I could look up to, or even the other way round; this is one of the things that I definitely will not do in the future; I will not be like the teachers I have met so far), the sentence pattern is changed (this I won't do, teachers; unbelievable things she comes up with). Utterances on this subject are accompanied by raised intonation and lively gestures of the interlocutors/speakers.

The character of the chosen themes is not neutral, their analysis shows the far-reaching critique of the attitudes and behaviors of contemporary teachers. At the same time the students -future teachers - present themselves as those who can introduce changes. Therefore the analysis reveals the so-called "group polarization scheme" (van Dijk, 2000, p. 35) based on two discursive strategies: emphasizing the students' own good qualities and actions (positive self-presentation), and emphasizing the bad qualities and actions of school teachers (negative presentation of others). Negative predicates regarding the teacher were used (uncompromising, incompetent, unfair, irresponsible, infallible, all-knowing) while positive predicates were used in self-presentation (a true teacher, a teacher by vocation). The aim of this treatment is to build up the differences between teachers-practitioners and students -future teachers.

The evaluative theses, the manner in which they were argued for, and the presented image of students were constructed using emotional arguments. The arguments were based on individual experience; however, due to the fact that they were invoked by all students, they constitute a commonly shared view of the students' reality. The analysis of argumentative structure shows that the students define the situation themselves and they are ready to reject any other definition that might arise. This emotion-loaded way of imaging reality imposes an interpretation which is consistent with the speaker's intention: the desire to convince others of their theses and conclusions. Furthermore, basing theses on the so-constructed mental schema does not require providing justification for the declared strategy of making changes included in the conclusion (to make changes you need to cheat/swindle and be crafty).

Cataloguing evaluative expressions makes it possible to discern the presuppositions that may be expressed by the following statements: it is us who have a vision of a good teacher, 
it is us who are prepared to implement the long-pending changes in education. Although they are not verbalized, they are present in the utterances (e.g., fortunately the old teaching personnel is going to retire soon, in 20-30 years' time the situation will be different; eventually others will act as I do; I will show them what it means to be a teacher by vocation; our lessons will exhibit our competences; unfortunately they do not give us any chance to present our abilities; they make us write these nonsense lessons plans). These presuppositions are tentative and unverifiable. Emotion-loaded arguments are used to confirm the recipient in the conviction that the arguments are true and indisputable, since the adoption of such a perspective is a prerequisite for accepting other statements as true.

Table 1. Image of self and others presented in an evaluative manner

\begin{tabular}{|c|c|}
\hline We - what we are like & They - what they are like \\
\hline $\begin{array}{l}\text { we succeed, a real teacher, teacher by vocation, } \\
\text { we have will, we know, we are suppressed, like } \\
\text { coffee and sugar, I will be fair, I will be a good } \\
\text { teacher }\end{array}$ & $\begin{array}{l}\text { an obvious example of what not to do, the first } \\
\text { thing that strikes me is the incompetence, they beli- } \\
\text { eve they are infallible, their knowledge is incomple- } \\
\text { te, completely irresponsible, they think they are the } \\
\text { wisest people in the world, they are not committed, } \\
\text { they don't realize civilization has changed over the } \\
\text { years, the teacher-guru, there are not teachers by } \\
\text { vocation, they feel unpunished, why do they work } \\
\text { in school at all, they think they know it all, young } \\
\text { teachers are old-fashioned too }\end{array}$ \\
\hline We (will) do & They do \\
\hline $\begin{array}{l}\text { show teachers what they are doing wrong, inspire } \\
\text { to act, not demand obedience and replication of } \\
\text { my thoughts, have a partner relationship with pu- } \\
\text { pils, focus on communication rather than teaching, } \\
\text { I will teach using my methods, clash with these te- } \\
\text { achers, I am driven by a desire to show that other } \\
\text { methods are possible, my lessons will be different, } \\
\text { I will achieve the goals I have set, If I am to teach } \\
\text { I will do it well, we will not copy the old patterns, I } \\
\text { will fight off any attacks }\end{array}$ & $\begin{array}{l}\text { evaluate unfairly, require unbelievable things from } \\
\text { students, blindly follow guidebooks, function as } \\
\text { part of the system, act schematically, do their duti- } \\
\text { es, go home and are no longer bothered }\end{array}$ \\
\hline
\end{tabular}

Source: own

The conceptual structure used by the students in their thinking processes and their interpretation of the facts builds a conceptual frame which, at the same time, expresses their attitude toward the presented world. This world is properly expressed in figurative language. Among figures of speech, metaphors deserve special attention as a way of constructing the world, the way it is categorized and conceptualized and as a tool of persuasion. 
Metaphor is a type of knowledge representation which characterizes human intellectual activity and reflects our thinking. "Metaphors provide the only way to perceive and experience much of the world" (Lakoff and Johnson, 1988, p. 226) and "give structure to our everyday system of concepts" (ibid., p. 239). Therefore the linguistic metaphor is a reflection of the conceptual metaphor. In the analyzed text, framing is based on using metaphors in relation to the teacher, education, school, school authorities and lesson. The analysis of metaphors helps us understand the experiences which are the basis for the conceptualization of these notions. The analysis of metaphors used in the text leads to the discovery that:

- school is stress; rigid model,

- a teacher is walking incompetence,

- classrooms/lessons are like bedlam,

- students are at the teacher's mercy for knowledge,

- students are strangled by teachers,

- teaching is a vicious circle, paperwork,

- the authorities put the skids under the teachers ${ }^{4}$.

\section{DISCUSSION}

The metaphors reveal that the constructed image of the world is a simplified version of the educational reality, it polarizes and categorizes the participants of the educational situation. Teachers are blamed for the difficult position of pupils in school, their irresponsible behavior, following the curriculum "blindly", their routine and obedience to the authorities. Students perceive themselves in the role of teachers as smothered by the authorities (a lot of paperwork, it is difficult to be satisfied with the work when there is always something you have to do, the curriculum is outdated-it does not bring in anything new, the curriculum is imposed by the authorities, we have no influence on the shape of the curriculum, we choose the government, we choose our president, but we do not decide what the school curriculum looks like).

Metaphorical saturation evokes emotions that enhance the persuasive impact. Speech act analysis allows us to assess the effectiveness of utterances. Due to the objectives of the research, commissive and directive speech acts were analyzed (Zdunkiewicz, 1993; Kaproń-Charzyńska, 2014). Commissives comprise utterances by which the speaker defines her behavior in the future. In the analyzed text commissives express readiness to make changes. The statements take two forms:

- promises to take action, but without any obligation to the recipient (I want to show teachers what they have done wrong for all these years, I want to clash with those teachers; I will be a just teacher; we will write all these lessons plans, but do our own thing in the classroom; we will fight against this rigid model, I have this desire to show that it is possible to be a good teacher; I will be the true teacher we are talking about:

4 The metaphors were translated into English but their intended meaning was preserved. 
the one who develops students' passions and shows the way to acquire knowledge; I will build relationships with students and teach classes in a way that is different from what we have seen; our lessons will be the best proof of our competence; I will teach using my own methods; I will refute criticism by presenting some evidence: I will pay attention to the fact that each student has a different approach to knowledge and thinks differently; I will do that so eventually other teachers will follow my example; these rigid lesson plans are horror, I am obliged to write them and I will write them, but I won't use them in the classroom; we will cheat; I will be a crafty teacher; I will achieve the goals I have set);

- and promises to abandon certain practices (I will not do any of the things my teachers did; I will not demand obedience and replication of my thoughts; I will not show the students that only I am right).

Directives take three forms:

- non-binding commands that take on the nature of advice addressed to teachers (put your college notes in the dustbin and do not use them in the classroom; create something new; more variety, less copying during classes - do not be like: now we are going to read, discuss, write; open up to discussion, it is a good method of work - it is not disorganization; be flexible; dear teachers, read what group work is all about; do not be such a bore; do not judge too quickly; allow students to have their own opinion; make students interested in the topic; do not expect only standard answers from your students)

- complaints that are not addressed to a specific recipient (nobody does anything about the stupidity of teachers; such a reform makes no sense at all; the department should react, make a difference, but they will not; the curriculum is inadequate for the reality; they do not do anything about it because they do not feel the need to do it - that is the way it is and that is what you should do)

- complaints-questions (where do you send us to do our undegraduate internship, where and with whom?!; why doesn't anybody do something about it?!; how am I supposed to fight against this rigid model when I am obliged to implement it?!).

The analysis of commissives may indicate that the construction of changes has a general character. Promises are not substantiated here, most of them are built on an opposition to the current state of affairs. However, since negation of existing work practices is documented in the discourse, it may be concluded that the pieces of "good advice" addressed to teachers and included in directives are likely be fulfilled in the future because students express approval of these rules explicitly. The analysis does not reveal any intention to enforce the recommendations; moreover, there are no intentions to persuade teachers to apply them. This is not due to the asymmetric relationships that characterize both education participants (students and teachers), but due to the belief which is included in the presupposition.

The analyzed discourse is a digressive discourse which is characterized by associative cohesion. A straight line of narrative progression cannot be determined, enumeration and 
emotionally charged expressions occur. Utterances are built in the language of "I" and "we". References to the past and present are dominated by utterances in the first person plural, references to the future are in the first person singular. The analysis enables the consideration of the following question: what kind of cognitive and emotional discursive community do the participants form? It is the question of who the author of the discourse is. The author is not identical with the person who delivers a text but it is defined as

the unifying principle in a particular group of writings or statements, lying at the origins of their significance, as the seat of their coherence. (...) The author is he who implants, into the troublesome language of fiction, its unities, its coherence, its links with reality (Foucault, 1972, pp. 221-222).

The author of the examined discourse is the representative of the young future teachers who are ready for changes in education. She thinks and speaks of herself as the guarantor of change. This community is based on emphasizing the differences and variances between members of the community and school teachers. This leads to the formation of confrontational and competitive attitudes. A significant increase in this feature promotes the growth of internal cohesion of the group and makes affiliation with this group more attractive.

By giving themselves the right to make changes, members of the community perceive themselves as experts. Such a procedure validates and legitimizes their actions and practices. They realize that their community is temporary, soon it will disperse when they enter the labor market to join the new community as novices. While within their community they create a professional discourse system, the fact that they stand up against the practices of the teacher community may suggest that after they have entered the labor market they will be placed in a new community, understood as an institutional discourse system. The only thing they will share with teachers will be their place of work - school as the institution.

\section{CONCLUSIONS AND RECOMMENDATIONS}

The presented analysis carried out within the framework of critical discourse analysis complements research on teacher education in the context of becoming a teacher. According to the principle that the researcher does not announce the truth, but instead only suggests interpretations and solutions to problems, several conclusions and recommendations for the practice of teacher education can be drawn. Studying and familiarizing oneself with the new concept of teacher practices changes the students' way of thinking about the role of the teacher in the social-constructivist model of education and builds critical skills and competences of the students. These in turn favor the change of activity of future teachers. The emancipatory influence of education may also be found in the discourse and is reflected in the manifestation of resistance to the old order. Not only do students refuse to accept externally imposed constraints and to fit in the already-existing 
patterns of action, but they also declare their readiness to take the risk of change. They define and design these changes.

The analyzed discourse represents one group's image of the world, it reflects its goals and values that are built in isolation from others. The uniformity of the world is complex and it results from common experiences, distrust and some sort of rebellion against the defined order. A distorted picture of the teacher and the school is built upon a lack of confidence in the authorities, the perception of others as enemies and a lack of faith in the possibility of joint action. In the analyzed text we find fragments that fit within the current stereotypes of "bad" schools and teachers who are reluctant to change. These stereotypes are common in social consciousness. A one-dimensional image is the starting point for the construction of a strategy which students will adopt in order to achieve their goals in the future. Because of the fact that the strategy is ethically questionable and embedded in stereotypes (all great things have their beginning in small frauds), it causes concern. Due to the high level of mistrust, it leads to polarization, impedes the entry to the labor market, and prevents building understanding and cooperation in teams.

The problem areas which were revealed in the analysis lead to the conclusion that it is necessary to introduce further changes in the undergraduate internship in pedagogy. The main change suggested would be the introduction and organization of activities based on a partnership between students-interns and teachers-tutors. A collaborative design of activities and the implementation of these projects in the classroom will help students to understand the teachers' working conditions and help teachers to incorporate elements of the new model of education into their own practices. It is also important that these meetings be cyclical - in the long term, they should contribute to the breaking down of the barrier of distrust and the monopoly of competence. Learning organized in such a way can break the patterns of meaning and help to organize experience in a different way. A confrontation of scientific and practical views of reality and the use of different perspectives in solving real-world problems also favor the creation of the third type of knowledge (Urbaniak-Zając, 2003, p. 287).

\section{REFERENCES}

Bauman, Z. (2000). Ptynna nowoczesność. Warszawa: Wydawnictwo Literackie.

Beck U., Giddens A. and Lash S. (2009). Modernizacja refleksyjna. Praktyka, tradycja i estetyka w porzqdku społecznym nowoczesności. Warszawa: PWN.

Bosančić, S. and Keller R. (2016). Perspektiven wissenssoziologischer Diskursforschung. Wiesbaden: Springer.

Bielecka-Prus, J. (2012). Problem kontekstu w teoriach komunikowania społecznego. Studia Socjologiczne, 1(204), 5-15.

Carr, W. and Kemmis, S. (1995). Becoming Critical. Education, Knowledge and Action Research. London and Philadelphia: The Falmer Press.

Foucault, M. (1972).The Archeology of Knowledge and the Discourse on Language. New York: Pantheon Books. 
Foucault, M. (2002). Porzqdek dyskursu. Gdańsk: słowo/obraz terytoria.

Gadamer, H. G. (2000). Rozum, stowo, dzieje. Szkice wybrane. Warszawa: PIW.

Gee, J. P. (2014). An Introduction to Discourse Analysis: Theory and Method. New York: Routledge.

Habermas, J. (1986). Pojęcie działania komunikacyjnego. Uwagi wyjaśniające. Kultura i Społeczeństwo, $3,21-44$.

Hejnicka-Bezwińska, T. (2008). Pedagogika ogólna. Warszawa: Wyd. Akademickie i Profesjonalne.

Jabłońska, B. (2013). Krytyczna analiza dyskursu w świetle założeń socjologii fenomenologicznej (dylematy teoretyczno-metodologiczne). Przeglad Socjologii Jakościowej, IX, 1, 48-61.

Jarvis, P. (2012). Osobowe uczenie się: uczenie się w działaniu. In W. Jakubowski (Ed.), Kultura jako przestrzeń edukacyjna (pp. 9-26). Kraków: Oficyna Wydawnicza Impuls.

Kaproń-Charzyńska, I. (2014). Pragmatyczne aspekty stowotwórstwa. Funkcja ekspresywna i poetycka. Toruń: Wydawnictwo Naukowe Uniwersytetu Mikołaja Kopernika.

Kubinowski, D. (2010). Jakościowe badania pedagogiczne. Filozofia - Metodyka - Ewaluacja. Lublin: Wydawnictwo UMCS.

Lakoff, G. and Johnson M. (1988). Metafory w naszym życiu. Warszawa: PWN.

Lisek-Michalska, J. (2013). Badania fokusowe. Problemy metodologiczne i etyczne. Łódź: Wydawnictwo Uniwersytetu Łódzkiego.

Malinowska, J. (2014). Między edukacją akademicką a rynkiem pracy - rozpoznanie kompetencji przyszłych nauczycieli. In W. Żłobicki (Ed), Transgresje w edukacji. Tom 1 (pp. 99-110). Kraków: Oficyna Wydawnicza Impuls.

Mannheim, K. (2008). Ideologia i utopia. Warszawa: Wyd. Altheia.

Niżnik, (1996). Habermas, Rorty, Kotakowski: Stan filozofii wspótczesnej. Warszawa: Wydawnictwo IFiS PAN.

Parker, I. (2004). Discourse Analysis. In U. Flick, E. V. Kardoff and I. Steinke (Eds.), A Companion to Qualitative Research (pp. 308-312). London: Sage Publication.

Rancew-Sikora, D. (2007). Analiza konwersacyjna jako metoda badania rozmów codziennych. Warszawa: Wydawnictwo Trio.

Rodziewicz, E. (2011). Przeobrażenia kontekstów kultury europejskiej a kondycja pedagogiki - dzisiaj. In T. Hejnicka-Bezwińska (Ed.), Pedagogika ogólna. Dyskursy o statusie naukowym i dydaktycznym (pp. 42-57). Bydgoszcz: Wydawnictwo Uniwersytetu Kazimierza Wielkiego.

Swales, J. M. (1990). Genre analysis. English in academic and research settings. Cambridge: Cambridge University Press.

Szempruch, J. (2013). Pedeutologia: studium teoretyczno-pragmatyczne. Kraków: Oficyna Wydawnicza Impuls.

Teacher Education Standards (2012). Retrieved from http://dziennikustaw.gov.pl/du/2012/131/1.

Urbaniak-Zając, D. (2003). Pedagogika społeczna w Niemczech. Stanowiska teoretyczne i problemy praktyki. Łódź: Wydawnictwa Uniwersytetu Łódzkiego.

Van Dijk, T. A. (2000). Opinions and Ideologies in the Press. In A. Bell and P. Garrett (Eds.), Approaches to Media Discourse (pp. 21-63). Oxford: Blackwell Publisher.

Van Dijk, T. A. (2001). Dyskurs jako struktura i proces. Warszawa: PWN.

Van Dijk, T. A. (2006). Badania nad dyskursem. In A. Jasińska-Kania (Ed.), Wspótczesne teorie socjologiczne (pp. 1020-1046). Warszawa: Wydawnictwo Naukowe Scholar.

Zdunkiewicz, D. (1993). Akty mowy. In J. Bartmiński (Ed), Wspótczesny język polski (pp. 259-270). Wrocław: Wydawnictwo Wiedza o Kulturze.

Zemło, M. (2006). Pragmatyczny model socjologii wiedzy. In P. Bytniewski and M. Chałubiński (Eds.), Teoretyczne podstawy socjologii wiedzy (pp. 25-37). Lublin: Wydawnictwo UMCS. 